\title{
Methods of oestrus prevention in dogs and cats: a survey of Turkish veterinarians' practices and beliefs
}

\author{
Métodos de prevención de estro en perros y gatos: una encuesta sobre las prácticas \\ y creencias de médicos veterinarios de Turquía \\ BH Sontas ${ }^{\mathbf{a}^{*}, \text { F Kaysigiz }}{ }^{\mathrm{b}}$, H Ekici ${ }^{\mathrm{a}}$ \\ ${ }^{a}$ Department of Obstetrics and Gynaecology, Faculty of Veterinary Medicine, Istanbul University, Istanbul, Turkey. \\ bDepartment of Animal Husbandry, Faculty of Veterinary Medicine, Istanbul University, Istanbul, Turkey.
}

\begin{abstract}
RESUMEN
Trescientos dos practicantes privados trabajando en Estambul, Ankara y Bursa y 35 miembros de Facultad pertenecientes a las Escuelas Veterinarias de Estambul, Ankara y Uluadg (Bursa) fueron encuestados mediante una entrevista personal, con el objeto de investigar las actitudes de los Médicos Veterinarios de Turquía hacia los métodos usados para la prevención de estro en perros y gatos, técnicas quirúrgicas para la esterilización, la edad a la cual los animales eran esterilizados y los materiales de sutura usados durante las cirugías. La mayoría de los veterinarios $(60,2 \%)$ estaban a favor de la contracepción quirúrgica en perros y gatos y se determinó que la ovariohisterectomía era la técnica quirúrgica más común ( $97 \%)$. En perros, los veterinarios practicantes, comparado a especialistas, realizaron esterilización quirúrgica después del año de vida $(\mathrm{P}<0,001)$. Sin embargo, en gatos, los especialistas prefirieron realizar la cirugía después del año de edad (9,8\% vs. 25,9\%) comparado a practicantes. Para la esterilización quirúrgica, la aproximación media ventral fue más común en perros $(85 \%)$ mientras que en gatos la aproximación de flanco fue preferida $(65 \%)$. El medicamento de primera opción para la contracepción fue el acetato medroxiprogesterona $(68,8 \%)$ y $24 \%$ de los veterinarios consideró usar medicamentos sin licencia veterinaria para la prevención de estro en perros y gatos.
\end{abstract}

Key words: dog, cat, reproduction, contraception, spaying, progesterone.

Palabras clave: perro, gato, reproducción, contracepción, esterilización, progesterona.

\section{INTRODUCTION}

In dogs and cats, breeding can be prevented by confinement of the female from the onset of prooestral vaginal bleeding to the onset of dioestrus or oestrus can be prevented by administration of progestagens such as medroxyprogesterone acetate (MPA), proligestone (PGS) and megoestrol acetate (MA), synthetic analogues of testosterone (androgens) or long-acting gonadotropinreleasing hormone $(\mathrm{GnRH})$ agonists (Romagnoli and Sontas 2010). Oestrus can also be prevented immunologically via antifertility vaccines or surgically by ovariectomy (OVE) or by ovariohysterectomy (OVH) (Concannon and Meyers-Wallen 1991, Howe 2006, Kutzler and Wood 2006, Purswell and Kolster 2006). Among these methods, antifertility vaccines are still under investigation and may be available in the future. The decision of which method to use depends on several factors related to the animal such as age, breed, temperament and intended use, the household environment, and the social, ethical, economical and regulatory guidelines of the practicing country. Therefore, the most common approach to oestrus prevention may differ among countries.

Accepted: 09.03.2012.

* Section for Obstetrics and Reproduction, University of Veterinary Sciences, Viena, Austria; Hasan. Sontas@ vetmeduni.ac.at
In Norway, routine surgical sterilization is prohibited by the Animal Welfare Act whereas in Sweden, Denmark, Finland and Germany, surgical contraception is not prohibited but removal of organs or parts of animals for the purpose of convenience to humans is discouraged (Farstad 2004). On the contrary, surgical contraception via OVH is the most common approach in the United States (US) because of the lack of drugs labeled for reproductive uses in dogs and cats (Spain et al 2002). In many European countries, both surgical and non-surgical methods are performed and many drugs approved for the control of reproduction are commercially available. Furthermore, there is no worldwide consensus among veterinarians regarding the best surgical technique (OVE vs. OVH) or the best age for surgical sterilization (prepubertal vs. postpubertal).

Public opinion in many European countries and in the US as well as in Turkey is becoming increasingly more sensitive to welfare issues for companion animals and as a consequence the usefulness and practical consequences of the methods used to control oestrus are currently being questioned by pet owners. The objective of this survey was to investigate the attitudes and practices used by Turkish veterinarians to control oestrus in dogs and cats. In this study, contraception excluded any method for termination of pregnancy but included any method for oestrus prevention in dogs and cats. 


\section{MATERIAL AND METHODS}

A list of private practices with a mailing address in Istanbul $(n=293)$, Ankara $(n=69)$ and Bursa $(n=91)$ was obtained from the Chambers of Veterinary Surgeons of these cities. Faculty members specializing in reproduction working in veterinary medicine colleges of Istanbul $(\mathrm{n}=14)$, Ankara $(\mathrm{n}=10)$ and Uludag (Bursa, $\mathrm{n}=11$ ) were also included in the study. The cities with: a) the highest estimated population of dogs and cats $\left.{ }^{1}, b\right)$ the highest number of small animal veterinary practices and c) the presence of a faculty of veterinary medicine were chosen for the study.

Data were collected between October 15, 2007 and May 15, 2008 by performing door-to-door survey with the first named partner within the practice. Nine fourth year veterinary students received 8 training sessions from one of the co-authors (Kaysigiz F.) on how to ask the questions consistently and record them correctly on the form. A maximum of two attempts were made to interview each veterinarian. Prior to the survey, the veterinarians were informed about the aim, methodology and the voluntary nature of the study. It was emphasized that any personal informations as well as the survey forms would be confidential.

The survey consisted of 43 questions that required either categorical or numeric answers. In addition, three questions invited written answers or comments. The survey was divided into three sections. The first section asked for demographic information (gender, age, year and school of graduation, years in clinical practice and number of practicing veterinarians etc.). The second section related to practices and beliefs regarding controlling oestrus. The last section related to the technique and materials used for surgical control of reproduction. The data were analysed by frequency analysis using statistical packages for social sciences for Windows 11.5 package program (SPSS). A chi-square test was used to investigate the effects of gender, title (general practitioner or veterinary specialist in reproduction), year and school of graduation on the variables including the method used for oestrus control, the age of surgical sterilization both in dogs and cats, and surgical approach for sterilization.

\section{RESULTS}

From 453 private practitioners $302(67 \%)$ participated in the study whereas all the faculty members $(n=35,100 \%)$ participate. Private practitioners who did not participate had moved or had given incorrect address $(n=53)$; been unreachable $(n=47)$ or refused $(n=51)$. Two-hundred and eighty-six veterinarians were practitioners whereas 51

Türkiye İstatistik Kurumu. 2009. Adrese dayalı Nüfus kayıt sistemi 2008 Nüfus sayımı sonucları. http://www.tüik.gov.tr/PreHaberBultenleri.do?id=3992. Accessed March 23, 2011. were specialized in reproduction $(n=38$, including the faculty members), surgery $(n=8)$ and internal medicine $(\mathrm{n}=5)$. In total the response rate was $69.1 \%(337 / 488)$ and the overall refusal rate was $11.3 \%$. Therefore, not all the veterinarians answered every question. And thus the number of responses varied for each question. Furthermore, veterinarians commonly answered questions on the drugs used for medical control of oestrus or the suture materials used for sterilization with more than one answer (e.g. multiple preferences). Demographic characteristics of the veterinarians are given in table 1.

METHODS FOR CONTROL OF REPRODUCTION IN DOGS AND CATS

Regarding the most common method used to control oestrus in dogs and cats, $60.4 \%$ of veterinarians favored only surgical methods (204/338) and $2.1 \%$ (7/338) did not recommend surgery at all (table 2 ). The method used for oestrus prevention was not influenced by the gender $(P=0.096)$, age $(P=0.202)$, title $(P=0.194)$, school $(\mathrm{P}=0.559)$ or year of graduation $(\mathrm{P}=0.248)$. Thirtythree per cent of the veterinarians (112/338) used both surgery or exogenous hormones for oestrus suppression. One veterinarian indicated that he/she used intrauterine devices in dogs before the device was taken off the market. Seventy-seven veterinarians indicated that they used progestagens including MPA $(n=58)$, PGS $(n=14)$ and MA $(n=8)$ (table 3). Gonadotropin-releasing hormone agonist implants were used by only seven veterinarians. Regarding whether they routinely used non-veterinary licensed drugs for oestrus control in dogs and cats, $24 \%$ (80/333) reported "yes" whereas 76\% (253/333) reported "no". Of those who answered "yes", the non-veterinary licensed drugs cited included MPA $(n=42)$, a combination of oestradiol benzoate and progesterone $(n=11)$, hydroxyprogesterone $(n=10)$, etonogestrel $(n=1)$ and testosterone $(\mathrm{n}=1)$.

\section{SURGICAL TECHNIQUES}

When asked about the surgical technique, $97.3 \%$ $(326 / 335)$ of the veterinarians indicated $\mathrm{OVH}$, and $2.4 \%$ $(8 / 335)$ indicated OVE as the preferred surgical technique (table 4$)$. One veterinarian $(0.3 \%)$ reported that he preserved one of the ovaries in it's anatomical location while removing the uterus with the opposite ovary (hemiovariohysterectomy). Sterilization procedure was performed in almost all the practices $(98.8 \%)$. To the question "Who spays dogs and cats at the practice?", 241 veterinarians indicated a full time practitioner, 68 indicated a full-time practitioner specialized in reproduction/surgery, four indicated a part-time practitioner, three indicated a veterinarian specialized in reproduction/surgery only called for the surgery and 18 indicated a full time practitioner and/ or a veterinarian specialized in reproduction/surgery not 
Table 1. Demographic information of 338 veterinarians participating in the survey.

Información demográfica de 338 MédicosVeterinarios que participaron en la encuesta.

\begin{tabular}{llrr}
\hline Characteristic & Categories & Number & Per cent (\%) \\
\hline Gender (313 responses) & Male & 198 & 63.3 \\
Age (years) (305 responses) & Female & 115 & 36.7 \\
& $20-29$ & 97 & 31.8 \\
& $30-39$ & 133 & 43.6 \\
& $40-49$ & 63 & 20.7 \\
Year of graduation (304 responses) & $50-59$ & 11 & 3.6 \\
& $\geq 60$ & 1 & 0.3 \\
& $<1980$ & 5 & 1.7 \\
& $1980-1985$ & 13 & 4.3 \\
Years in clinical experience (304 responses) & $1986-1990$ & 33 & 10.9 \\
& $1991-1995$ & 53 & 17.4 \\
Title (304 responses) & $1996-2000$ & 102 & 33.5 \\
& $2001-2006$ & 98 & 32.2 \\
Practice size (337 responses) & $1-4$ & 81 & 26.7 \\
& $5-9$ & 101 & 33.2 \\
& $10-19$ & 105 & 34.5 \\
& $>20$ & 17 & 5.6 \\
& Practitioner & 253 & 83.2 \\
& Specialized (Reproduction) & 38 & 12.5 \\
& Specialized (Surgery) & 8 & 2.6 \\
& Specialized (Internal Medicine) & 5 & 1.7 \\
& 1 veterinarian & 105 & 31.1 \\
& 2 veterinarians & 103 & 30.6 \\
& 3 veterinarians & 36 & 10.7 \\
& $\geq 4$ veterinarians & 93 & 27.6 \\
& Istanbul & 164 & 53.9 \\
& Ankara & 59 & 19.4 \\
& Bursa & 47 & 15.5 \\
& Other & 34 & 11.2 \\
\hline
\end{tabular}

Table 2. Method for oestrus prevention in dogs and cats (338 responses). respuestas)

Método de prevención de estro en perros y gatos (338

\begin{tabular}{lrc}
\hline Method & Number & Percentage \\
\hline Only surgery & 204 & 60.4 \\
Only medical & 4 & 1.2 \\
Only physical confinement & 3 & 0.9 \\
Intrauterine device & 1 & 0.3 \\
Either surgery or medical & 112 & 33.1 \\
Either surgery or physical & 9 & 2.7 \\
confinement & & \\
Depends on the patient & 5 & 1.5 \\
\hline
\end{tabular}

Table 3. Drugs for non-surgical contraception in dogs and cats. MA: Megoestrol acetate; MPA: Medroxyprogesterone acetate; PGS: Proligestone; GnRH gonadotropin-releasing hormone (77 responses).

Medicamentos para la contracepción no quirúrgica en perros y gatos. MA: acetatomegostrol; MPA: acetato medroxiprogesterona; PGS: proligestona; GnRH: hormona liberadora de gonadotrofina (77 respuestas).

\begin{tabular}{lrc}
\hline Drug & Number & Percentage \\
\hline MA & 5 & 6.5 \\
MPA & 53 & 68.8 \\
PGS & 7 & 9.1 \\
GnRH & 4 & 5.2 \\
Either MA or MPA & 1 & 1.3 \\
Either MPA or PGS & 2 & 2.6 \\
Either GnRH or PGS & 3 & 3.9 \\
Any type of progestagens & 2 & 2.6 \\
\hline
\end{tabular}


Table 4. Surgical technique for sterilization of female companion animals. OVH Ovariohysterectomy, OVE Ovariectomy. (335 responses).

Técnica quirúrgica para la esterilización de mascotas hembras. OVH: ovariohisterectomía; OVE: Ovarioctomía (335 respuestas).

\begin{tabular}{lcc}
\hline Surgical technique & Number & Percentage \\
\hline OVH & 326 & 97.3 \\
OVE & 8 & 2.4 \\
Hemi-OVH & 1 & 0.3 \\
\hline
\end{tabular}

employed by the establishment. When asked whether they had had an opportunity to perform a spaying procedure during undergraduate training, the majority of the veterinarians 93\% (295/317) answered "yes". However, to the question "Where did you learn to spay dogs and cats?", the most common answer was through: undergraduate training ( $\mathrm{n}=137$ ), followed by "learned from a colleague whom they worked with early in the career $(n=90)$ ", then "selftaught after they had opened their own practices $(n=47)$ ", "extramural experience $(\mathrm{n}=44)$ ", "specialization training $(\mathrm{n}=15)$ ", "books $(\mathrm{n}=3)$ )" and "animal shelter $(\mathrm{n}=1)$ )".

Most dogs and cats were spayed when the animals were approximately 7 months old or older (dogs: $79.8 \%$, cats: $79.5 \%$ ) (table 5). In dogs, the age of surgical sterilization was not influenced by gender $(\mathrm{P}=0.339)$ or school $(\mathrm{P}=0.604)$ but was influenced by title $(\mathrm{P}<0.001)$, age $(\mathrm{P}<0.001)$ and year of graduation $(\mathrm{P}<0.05)$. Specialists $(\mathrm{n}=51)$ significantly preferred to sterilize dogs between 7 to 12 months of age $(43.1 \%, \mathrm{P}<0.001)$ whereas practitioners $(40.7 \%, \mathrm{P}<0.001)$ waited until one year of age. Furthermore, veterinarians $(49.2 \%)$ aged between 40 and 49 years and graduated between 2001 and 2006 (80\%) significantly preferred to wait until the dogs were more than a year old $(\mathrm{P}<0.01$ and $\mathrm{P}<0.05)$. In cats, the age of sterilization was not influenced by gender $(\mathrm{P}=0.142)$, age $(\mathrm{P}=0.061)$, school $(\mathrm{P}=0.895)$ or year of graduation $(\mathrm{P}=0.678)$ but it was by title $(\mathrm{P}<0.001)$. Although, both specialists and practitioners more commonly performed sterilization between seven to 12 months of age in cats, specialists performed the surgery more commonly before one year of age $(9.8 \%$ vs. $25.9 \%)$. The benefits indicated for sterilization before 7 months of age while practice is more commonly after one year of age were: minimal intraor post-operative complications $(n=58)$, easier surgery $(n=38)$, less anaesthetic complications $(n=20)$ and other $(\mathrm{n}=54)$. In addition, under the category "other", lowered risk of mammary tumour $(n=32)$ was mentioned. The veterinarians who were concerned about problems related to growth $(n=43)$, hormonal disturbances $(n=10)$, behaviour $(n=1)$ and secondary sexual characteristics $(n=1)$, sterilized dogs and cats after 12 months of age. Seven veterinarians said that they performed the surgery any time according to the owners' request and one individual indicated that the time of surgery depended on the breed of the animal.

Most of the veterinarians $(85 \%)$ performed $\mathrm{OVH}$ through a ventral midline approach in dogs whereas the majority of the veterinarians $(65 \%)$ preferred a lateral flank approach in cats (Table 6). In dogs, the surgical approach was not influenced by gender $(\mathrm{P}=0.606)$, title $(\mathrm{P}=0.266)$ or veterinary school $(\mathrm{P}=0.205)$ but was influenced by age $(\mathrm{P}<0.01)$ and year of graduation $(\mathrm{P}<0.05)$. On the other hand, in cats, the approach for sterilization was only influenced by school of graduation $(\mathrm{P}<0.05)$. Veterinarians aged between 20 and 39 years preferred a midline approach compared to those aged 40 and more $(\mathrm{P}<0.01)$. In dogs, flank approach was more commonly performed by the veterinarians graduated between 2001 and 2006 ( $\mathrm{P}<0.05)$. In cats, ventral medline was more commonly performed by the veterinarians graduated from Istanbul and Uludag than those graduated from other veterinary schools $(\mathrm{P}<0.05)$.

The ligature materials used for surgical sterilization were reported as follows: polyglactin $910(n=152)$, chromic catgut $(n=151)$, plain catgut $(n=60)$, silk $(n=40)$ and non-absorbable monofilament material $(n=3)$. Regarding whether animals were hospitalized after completion of the surgery, 69\% reported "yes" whereas 31\% reported "no". Veterinarians who indicated that the animals were hospitalized postoperatively indicated that they hospitalized for $0-3$ days $(67.4 \%),>3$ and $<5$ days $(12.6 \%), 5$ to 7 days $(19.1 \%)$ and $>7$ days $(0.9 \%)$.

Table 5. Recommended age for surgical sterilization in dogs (337 responses) and in cats (337 responses).

Edad recomendada para la esterilización quirúrgica en perros (337 respuestas) y en gatos (337 respuestas).

\begin{tabular}{|c|c|c|c|c|c|}
\hline \multirow{2}{*}{ Age } & \multicolumn{2}{|c|}{ Dogs } & \multirow{2}{*}{ Age } & \multicolumn{2}{|c|}{ Cats } \\
\hline & Number & Percentage & & Number & Percentage \\
\hline$<4$ months & 1 & 0.3 & $<4$ months & 4 & 1.2 \\
\hline 4-6 months & 64 & 18.7 & 4-6 months & 60 & 17.8 \\
\hline 7-12 months & 144 & 42.7 & 7-12 months & 191 & 56.7 \\
\hline$>12$ months & 124 & 37.1 & $>12$ months & 77 & 22.8 \\
\hline After 1st whelping & 1 & 0.3 & After 1st whelping & 1 & 0.3 \\
\hline Depends on the breed & 1 & 0.3 & I do not recommend & 4 & 1.2 \\
\hline I do not recommend & 2 & 0.6 & & & \\
\hline
\end{tabular}


Table 6. Surgical approach for sterilization in dogs (333 responses) and in cats (331 responses).

Aproximación quirúrgica para la esterilización en perros (333 respuestas) y en gatos (331 respuestas).

\begin{tabular}{lccllcc}
\hline \multirow{2}{*}{ Surgical approach } & \multicolumn{2}{c}{ Dogs } & & \multicolumn{2}{c}{ Cats } \\
\cline { 2 - 3 } & Number & Percentage & & & & Pergicentagproach \\
\hline Midline & 283 & 85 & & Midline & 102 & 30.8 \\
Flank & 42 & 12.6 & & Flank & 215 & 65 \\
Depends & 8 & 2.4 & & Depends & 14 & 4.2 \\
\hline
\end{tabular}

Twenty-four percent of the veterinarians (81/332) (24.4\%) recommended whelping before surgical sterilization because of a particular benefit whereas another 14/332 (4\%) recommended only if the owner had requested. The opinions for recommending whelping first were as follows: every animal should experience maternity and lactation $(n=23)$, hormonal imbalances can be prevented $(n=18)$, number of companion animals should be increased $(n=9)$, breed's characteristics should be preserved $(n=7)$, neoplastic diseases of the reproductive system can be prevented $(n=5)$, risk of developing pyometra can be reduced $(n=1)$ and every animal has the right to reproduce $(\mathrm{n}=1)$.

\section{DISCUSSION}

The results of this survey indicated that surgical sterilization, particularly $\mathrm{OVH}$ was the most common method used for oestrus prevention in dogs and cats in Turkey. Although most dogs and cats were sterilized after 7 months of age, specialization in veterinary reproduction had a significant influence on the age at which the animals were sterilized. The surgical approach (ventral midline vs. flank) depended on whether the patient was a dog or a cat, with flank approach, more common in cats.

The response rate for the present survey $(69 \%)$ seemed slightly below the recommended range of $75 \%$ or higher for face-to-face surveys (Langbein and Felbinger 2006) but significantly above those obtained in many surveys performed by mail questionnaires (9.6-57.8\%) (Watson et al 1996, Coe et al 2006, Hewson et al 2006, Murray et al 2008). The lower response rate in the present study related to the mailing list obtained from the Chambers of Veterinary Surgeons that contained several incorrect addresses. This was demonstrated by a study (Spain et al 2002) in which veterinarians updated incorrectly or had not regularly updated their occupational information annually due to heavy workload. Furthermore, a decline in the response rate to any kind of surveys in the past years has been indicated by Langbein and Felberg (2006). In this study, similar to the situation in the US (Spain et al 2002), the majority of the veterinarians preferred only surgical sterilization and about one third of the veterinarians used either surgical or medical approaches. Several reasons can be suggested why most of the Turkish veterinarians preferred surgery for the control of oestrus in small animals. According to the animal welfare law in Turkey $^{2}$, routine sterilization of dogs and cats is not prohibited, on the contrary surgical approach is encouraged to reduce stray animal overpopulation. Second, 91 per cent, 71 per cent and 57 per cent of the veterinary medicine colleges of Istanbul, Ankara and Bursa recommend only surgery, respectively, which is likely to influence this preference. Furthermore, the number of drugs available for oestrus prevention is limited in Turkey and consists of progestagens (MPA and MA) and androgens (methyl testosterone and testosterone esters). Currently, only MPA is licensed in Turkey for the veterinary use. Deslorelin (Suprelorin ${ }^{\circledR}$ ), a GnRH agonist implant is not available in Turkey while the paper was on preparation although it has become commercially available in other parts of Europe. Finally, the influence of the owners' preference (permanent vs. temporary control of reproduction) should also be taken into account.

Progestagens including MPA, MA, PGS, chlormadinone acetate and delmadinone acetate are commonly used (and sometimes misused) for the control of female reproduction by blocking the production and/or release of GnRH from the hypothalamus ${ }^{3}$. Medroxyprogesterone acetate is the most commonly used progestagen in this study. This may be due to it's long-acting nature, low-cost and wide availability as a veterinary or non-veterinary licensed drug. This long-acting progestagen is available as a veterinary formula in most European countries including Turkey, whereas in the US, MPA is no longer marketed as a veterinary drug (Concannon and MeyersWallen 1991). Androgens such as testosterone esters or methyl testosterones suppress gonadotropin release by a negative feedback upon the hypothalamic-pituitary axis. These drugs are frequently used to prevent oestrus and to increase muscle density in racing female Greyhound dogs in the United Kingdom (UK) (Gannon 1976). Except one individual, the use of androgens for this purpose was not preferred by Turkish veterinarians. Approximately one-

\footnotetext{
2 http://rega.basbakanlik.gov.tr/main.aspx?home=http://rega.basbakanlik.gov.tr/eskiler/2004/07/20040701.htm\&main=http://rega basbakanlik.gov.tr/eskiler/2004/07/20040701.htm, Animal Protection Law No 5199, Acceptance date June 24, 2006; accessed March 23, 2011.

3 Romagnoli S, PW Concannon. 2003. Clinical use of progestins in bitches and queens: a review. In: Concannon PW, England G, Verstegen J (eds). Recent advances in small animal reproduction. Ithaca: International Veterinary Information Service (www.ivis.org). Document $\mathrm{N}^{\circ} \mathrm{A} 1206.0903$. Accessed March 23, 2011.
} 
fifth of Turkish veterinarians prescribed non-veterinary licensed drugs for non-surgical contraception of dogs and cats. It is natural that a non-veterinary licensed drug will be used to treat a disease or a disorder when there is no corresponding medication licensed for animals. However, in our opinion, veterinarians should be encouraged by the manufacturers or by the authorities to use the veterinary licensed drugs when available.

Similar to the practices in the UK (England 2009), US (Salmeri et al1991), Canada (extrapolated from Hewson et al 2006) and Australia (extrapolated from Watson et al 1996), OVH is the most frequently performed surgical procedure for sterilization dogs and cats in Turkey. Although OVE is considered to be a less invasive and less stressfull surgical procedure for the animal, less-time consuming for the surgeon, and more economical surgery for the owner (Van Goethem et al 2006), it is not a common approach in the world except Europe. In the US and the UK, OVH is a more common approach because of the concerns about the possible development of uterine pathology following OVE. However, a study from Utrecht university (Okkens et al 1997), reports no differences between OVE and OVH regarding short-term as well as long-term surgical complications and the incidence of urinary incontinence in dogs. In our opinion, high interest for OVH shown by Turkish veterinarians is highly likely related to the undergraduate training and veterinary surgery textbooks. At the veterinary medical schools in Turkey, mainly OVH is taught and practiced in order to demonstrate the abdominal organs including the ovaries, uterus, urinary bladder, intestines and spleen and also to show the approach for a ceaserean section since a ventral midline incision for OVH provides a clear visualisation. In addition, $\mathrm{OVH}$ is recommended and described in detail by instructions or figures in several USA (Hedlund 1997, Fingland 1998, Stone 2003) and UK (White 1998, England 2009) based veterinary textbooks whereas OVE is either not described or only briefly mentioned. Hemiovariohysterectomy, which has been described as a surgical technique to reduce the side effects of total removal of oestrogen source by OVH or OVE (Arnold et al 2006), may result in development of neoplastic diseases such as granulosa cell tumors (Sivacolundhu et al 2001) or non-neoplastic conditions such as ovarian cysts (Sontas et al 2011). Therefore, the authors do not recommend this type of surgical approach and strongly recommend removal of both gonads by OVE or by OVH for the surgical prevention of oestrus in dogs and cats.

Although gonadectomy is one of the oldest surgical procedures in domestic animals, the best age for surgery is still a dilemma (Salmeri et al 1991). Until 1980's, the recommended age at which to spay dogs and cats was five to nine months of age due to the concerns on anaesthesia and surgical complications. However, development of safer anaesthetic protocols and suture materials enabled clinicians to spay sexually immature dogs and cats at the age of 6 to 14 weeks (Salmeri et al 1991, Fagella and Aronsohn 1994). The concept of sterilization before puberty often referred to as prepubertal gonadectomy, has been supported by several organizations in the US including the American Veterinary Medical Association and the American Animal Hospital Association to combat pet overpopulation problem. Also in the UK, the British Small Animal Veterinary Association and the Cat Group recommended surgery in cats at approximately 16 weeks of age (Murray et al 2008). In the US and UK, the mean age recommended for sterilization of client-owned animals was 5 and 6 months of age, respectively (Spain et al 2002, Murray et al 2008). However, for shelter animals, the recommended age was significantly earlier (3 months) (Spain et al 2002, Murray et al 2008). Due to the concerns about stunted growth, behavioural problems, hormonal disturbances and secondary sexual characteristics, the majority of the Turkish veterinarians recommended surgical sterilization after 7 months of age and only 1.5 per cent of the veterinarians considered surgical sterilization before 16 weeks of age. However, Turkish veterinarians aged between 40 and 49 years and graduated between 2001 and 2006 significantly preferred to wait until the dogs were more than a year old. For veterinarians aged between 40 and 49, it is highly likely that currently recommended age for sterilization by the teachers may vary from that taught to students in previous years. On the other hand, the same preference of the younger veterinarians might be related with the influence of the more experienced veterinarian(s) whom they started working with at the beginning of their career.

Ovariohysterectomy can be performed either through a ventral midline incision or through a lateral flank approach, also named as Viennese method (Dreier Von 2003, McGrath et al 2004). Several USA veterinary surgery books (Hedlund 1997, Fingland 1998, Stone 2003) describe the procedure only through the ventral midline approach whereas the flank approach is described only in the cats in UK and German based textbooks (White 1998, Dreier Von 2003). According to McGrath et al (2004), cats have a thinner body-wall musculature and a narrow abdominal width compared to most dogs which makes the entry into the abdominal cavity by flank approach in cats technically easier and less haemorrhagic and provides an easier access to the contralateral ovary. In this report, in accordance with previous studies (Tivers et al 2005, Coe et al 2006), flank approach was more commonly performed in cats although it causes significantly higher post-surgical wound tenderness score (Grint et al 2006). In this study, veterinarians aged younger than 40 preferred a midline approach probably because of the instructors in their veterinary colleges.

Catgut sutures (plain or chromic) are absorbable materials that are made of sheep or cattle small intestines (Boothe 1998). Despite having lower tensile strength and knot security and causing severe inflammatory and sensitivity reactions, this material is utilized for ligatures in OVH by most of the veterinarians surveyed in this study. Practitioners in the UK also preferred chromic catgut for the ligatures (Tivers et al 2005, Coe et al 2006) although production and use of this suture material is prohibited in 
the European Union (Seeger 2002). Interestingly, the use of polyglactin 910 (152/332 veterinarians) for the ligatures of reproductive organs was more common than reported by Tivers et al (2005) (38/181 veterinarians) and Coe et al (2006) (12/179 veterinarians). On the other hand, the number of veterinarians $(n=40)$ using non-absorbable materials including silk and monofilament sutures was significantly higher in this study compared to the studies mentioned above (Tivers et al 2005, Coe et al 2006). Veterinarians preferred non-absorbable materials probably because of the low cost and the excellent handling of these materials. However, nonabsorbable materials may produce long-term complications such as fistulous draining tracts at precrural, inguinal or sublumbar regions (Pearson 1973) and they are not recommended in the veterinary surgery books (Hedlund 1997, Fingland 1998, Stone 2003) or by the specialists $(0 \%)$ for sterilization procedures.

Greenfield et al (2004) highlights the importance of specialists in veterinary medical schools in preparation of new graduates for entry-level small animal practice. General and elective surgery skills are ranked as the most important skill for new veterinary school graduates by most of the private practitioners in the US (Greenfield et al 2004). The percentage of veterinarians (93\%) who had performed a sterilization procedure during undergraduate trainning was significantly higher than the percentage reported by Clark et al (2002). Of the 40 veterinarians who completed their training at Murdoch University, Australia, $76 \%$ had spayed a bitch and $41 \%$ had spayed a cat as a student. In the current study, despite a high attendance rate (93\%) to a sterilization surgery during undergraduate training, a large proportion of veterinarians $(26.7 \%)$ indicated that they learned to perform the surgery from more experienced associate veterinarians. This may be related to a low degree of interest of students to surgeries or to inadequate numbers of hands-on practice during veterinary training or with insufficient teaching methods or facilities at the universities. Nevertheless, approximately all the veterinarians had the skill to perform a sterilization procedure at the practice probably due to the high participation to the surgery during undergraduate training. However, the role of more experienced associate veterinarians in providing assistance and guidance to entry level veterinarians when performing a spay procedure should also be considered important.

One third of the veterinarians believed that dogs or cats should give birth before gonadectomy. It is not clear whether the benefits indicated by the veterinarians such as preservation of the breed's characteristics, increasing the population of companion animals, prevention of hormonal imbalances, owner's wishes, experiencing maternity, prevention of neoplastic diseases of the reproductive system and having the right to reproduce were based on scientific knowledge or humanitarian feelings or ethical values. Although no significant correlation was found between the development of mammary tumours in dogs and pregnancy (Brodey et al 1966), a significant association was determined between pyometra and parity (Johnston et al 2001).
The results of this survey indicate the considerable interest of Turkish veterinarians in surgical rather than medical prevention of oestrus. The lower frequency of use of medical contraception by Turkish veterinarians seemed to be related to the inadequate education and reveals the need for more continuing education courses. Practitioners should be fully educated about the advantages and disadvantages of each contraception method in order to select the best method for each patient and to fulfill the expectations of the owner. Furthermore, knowledge of non-surgical control of oestrus can be gained by participating in meetings dedicated to developing non-surgical technologies for the humane control of cat and dog reproduction such as those provided by "The Alliance for Contraception in Cats and Dogs". Finally, findings from the present study could be used as a basis to aid in the improvement of the small animal veterinary curriculum.

In conclusion, it is hoped that the data presented here could be used to develop strategies to increase the knowledge and skills of the current veterinarians regarding control of reproduction in female dogs and cats thus to improve the practice of oestrus prevention and to decrease the number of malpractice cases. Furthermore, knowing the most common surgical approach and suture materials used for sterilizations may help in reducing the short and long-term complications of the surgery through continuing education. The data obtained in this study regarding the drugs used for medical contraception may provide further impetus for the manufacturers to introduce new contraceptive drugs into Turkey. Finally, to the authors' knowledge no surveys have been conducted to specifically determine the attitudes and practices of veterinarians regarding methods used for oestrus prevention in dogs and cats in Turkey or elsewhere in the world.

\section{SUMMARY}

Three-hundred and two private practitioners working in Istanbul, Ankara and Bursa and 35 faculty members of veterinary medical schools of Istanbul, Ankara and Uludag (Bursa) were surveyed by a face-to-face interview to investigate the attitudes of Turkish veterinarians towards the methods used for oestrus prevention in dogs and cats, surgical techniques for sterilization, the age at which animals were spayed and the suture materials used in surgeries. Most of the veterinarians (60.4\%) favored surgical contraception in dogs and cats and ovariohysterectomy was determined to be the most common surgical technique (97\%). In dogs, compared with the specialists, practitioners performed surgical sterilization after one year of age $(\mathrm{P}<0.001)$. However, in cats, compared with practitioners, specialists preferred to perform the surgery after one year of age (9.8\% vs. $25.9 \%)$. For surgical sterilization, ventral midline approach was more common in dogs $(85 \%)$ whereas in cats flank approach was preferred (65\%). Medroxyprogesterone acetate was the primary drug of choice for medical contraception $(68.8 \%$ ) and $24 \%$ of the veterinarians considered using non-veterinary licensed drugs for the prevention of oestrus in dogs and cats.

\section{ACKNOWLEDGEMENT}

The authors would like to thank Görkem Tunca, Yeşim Tatan, Zuhal Aydogan, Zafer Dogan, Melih Çakın, Kasım Berber, Ahmet Topçu, Seher Yousefitebai and Berkay Yurtsever for performing the survey 
and Assoc. Prof. Dr. Bulent Ekiz (Department of Animal Breeding and Husbandry, Faculty of Veterinary Medicine, Istanbul University) for the statistical analysis.

\section{REFERENCES}

Arnold S, M Hubler, I Reichler. 2006. Weiblicher Geschlechtsapparat. In: Suter PF, Kohn B (eds). Praktikum der Hundeklinik. $10^{\text {th }}$ ed., Parey, Stuttgart, Germany, Pp 857-903.

Boothe HW. 1998. Suture materials, tissue adhesives, staplers, and ligating clips. In: Slatter D (ed). Textbook of Small Animal Surgery, $3^{\text {rd }}$ ed, Saunders, Philadelphia, PA, USA, Pp 235-244.

Brodey RS, IJ Fidler, AE Howson. 1966. The relationship of estrous irregularity, pseudopregnancy, and pregnancy to the development of canine mammary neoplasms. J Am Vet Med Assoc 149, 1047-1049.

Clark WT, L Kane, PK Arnold, ID Robertson. 2002. Clinical skills and knowledge used by veterinary graduates during their first year in small animal practice. Aust Vet $J$ 80, 37-40.

Coe RJ, NJ Grint, MS Tivers, A Hotston Moore, PE Holt. 2006. Comparison of flank and midline approaches to the ovariohysterectomy of cats. Vet Rec 159, 309-313.

Concannon PW, VN Meyers-Wallen. 1991. Current and proposed methods for contraception and termination of pregnancy in dogs and cats. J Am Vet Med Assoc 198, 1214-1224.

Dreier Von HK. 2003. Reproduktionmedizin: Gynakologie, Andrologie, Graviditat, Partus und Puerperium. In: Kraft W, Dürr UM, Hartmann K (eds). Katzen Krankheiten. Vol 2. $1^{\text {st }}$ ed. Verlag M \& H Schaper GmbH, Hannover, Germany, Pp 1108-1142.

England GCW. 2009. Genital surgery in the bitch and queen. In: Noakes DE, Parkinson TJ, England GCW (eds). Veterinary Reproduction and Obstetrics. 9 $^{\text {th }}$ ed. Saunders Elsevier, London, UK, Pp 376-390.

Fagella AM, MG Aronsohn. 1994. Evaluation of anesthetic protocols for neutering 6-to-14-week-old puppies. J Am Vet Med Assoc 205, 308-314.

Farstad W. 2004. The pros and cons of spaying the bitch; a practical and ethical dilemma. Biannual Congress of the European Veterinary Society for Small Animal Reproduction, Barcelona, Spain, Pp 121-126.

Fingland RB. 1998. Ovariohysterectomy. In: Bojrab MJ (ed). Current Techniques in Small Animal Surgery. $4^{\text {th }}$ ed. Williams and Wilkins, Baltimore, MD, USA, Pp 489-496.

Gannon J. 1976. Clinical aspects of the oestrus cycle in the greyhound. Racing Greyhound 1, 12-22.

Greenfield CL, AL Johnson, DJ Schaeffer. 2004. Frequency of use of various procedures, skills, and areas of knowledge among veterinarians in private small animal exclusive or predominant practice and proficiency expected of new veterinary school graduates. J Am Vet Med Assoc 224, 1780-1787.

Grint NJ, PJ Murison, RJ Coe, AE Waterman-Pearson. 2006. Assessment of the influence of surgical technique on postoperative pain and wound tenderness in cats following ovariohysterectomy. J Feline Med Surg 8, 15-21.

Hedlund CS. 1997. Surgery of the reproductive and genital systems. In: Fossum TW (ed). Small Animal Surgery. $1^{\text {st }}$ ed. Mosby-Year Book Inc., St. Louis, MO, USA, Pp 523-524.

Hewson CJ, IR Dohoo, KA Lemke. 2006. Perioperative use of analgesics in dogs and cats by Canadian veterinarians in 2001. Can Vet $J 47$, 352-359.
Howe LM. 2006. Surgical methods of contraception and sterilization. Theriogenology 66, 500-509.

Johnston SD, MVR Kustritz, PNS Olson. 2001. Cystic endometrial hyperplaisa-pyometra complex. In: Johnston SD, Kustritz MVR, Olson PNS (eds). Canine and Feline Theriogenology. $1^{\text {st }} \mathrm{ed}$. WB Saunders Company, Philadelphia, USA, Pp 207-220.

Kutzler M, A Wood. 2006. Non-surgical methods of contraception and sterilization. Theriogenology 66, 514-521.

Langbein L, CL Felbinger. 2006. Designing useful surveys for evaluation. In: Langbein L, Felbinger CL (eds). Public program evaluation: a statistical guide. $1^{\text {st }}$ ed. M.e. Sharpe Inc., NY, USA, Pp 192-217.

McGrath H, RJ Hardie, E Davis. 2004. Lateral flank approach for ovariohysterectomy in small animals. Comp Cont Edu Pract Vet 26, 922-931.

Murray JK, E Skillings, TJ Gruffydd-Jones. 2008. Opinions of veterinarians about the age at which kittens should be neutered. Vet Rec 163, 381-385.

Okkens AC, HS Kooistra, RF Nickel 1997. Comparison of longterm effects of ovariectomy versus ovariohysterectomy in bitches. $J$ Reprod Fertil (Suppl) 51, 227-231.

Pearson H. 1973. The complications of ovariohysterectomy in the bitch J Small Anim Pract 14, 257-266.

Purswell BJ, KA Kolster. 2006. Immunocontraception in companion animals. Theriogenology 66, 514-521.

Romagnoli S, BH Sontas. 2010. Prevention of breeding in the female. In: England GCW, Von Heimendahl A (eds). BSAVA Manual of Reproduction and Neonatology. 2nd ed. British Small Animal Veterinary Association, Gloucester, UK, Pp 23-33.

Salmeri KR, PN Olson, MS Bloomberg. 1991. Elective gonadectomy in dogs: A review. J Am Vet Med Assoc 198, 1183-1192.

Seeger T. 2002. Alternatives to catgut in bovine surgery. Praktisher Tierarzt 83, 910-915.

Sivacolundhu RK, AJ O'Hara, R Read. 2001. Granulosa cell tumour in two spayed bitches. Aust Vet J 79, 173-176.

Sontas BH, Milani C, Romagnoli S, Bertolini G, Caldin M, Caliari D, Zappulli V, Mollo A. 2011. A huge ovarian cyst in a hysterectomized bitch. Reprod Dom Anim doi: 10.1111/j.1439-0531.2011.01797.x. (Epub ahead of print).

Spain CV, JM Scarlett, MC Siobhan. 2002. When to neuter dogs and cats: A survey of New York State veterinarians' practices and beliefs. $J$ Am Anim Hosp Assoc 38, 482-488.

Stone AE. 2003. Ovary and uterus. In: Slatter D (ed). Textbook of Small Animal Surgery. $3^{\text {rd }}$ ed. Saunders, Philadelphia, PA, USA, Pp 1487-1502.

Tivers MS, TRD Travis, RV Windsor, A Hotston-Moore. 2005. Questionnaire study of canine neutering techniques taught in UK veterinary schools and those used in practice. J Small Anim Pract 46, 430-435.

Van Goethem B, A Schaefers-Okkens, J Kirpensteijn. 2006. Making a rational choice between ovariectomy and ovariohysterectomy in the dog: a discussion of the benefits of either technique. Vet Surg 35, 136-143.

Watson ADJ, A Nicholson, DB Church, MRB Pearson. 1996. Use of anti-inflammatory and analgesic drugs in dogs and cats. Aust Vet $J 74,203-210$.

White RN. 1998. Surgery of the genital tract. In: Simpson GM, England GCW, Harvey M (eds). British Small Animal Veterinary Association (BSAVA) Manual of Small Animal Reproduction and Neonatology. $1^{\text {st }}$ ed. Hampshire, UK, Pp 171-175. 


\section{Appendix \\ QUESTIONNAIRE}

Anexo 1. Cuestionario

Questionnaire

Establishment $\mathbf{N}^{\mathbf{0}}$ :

1) Gender:

a) Female

b) Male

2) Age:
a) $20-29$
b) $30-39$
c) $40-49$
d) $50-59$
e) $\geq 60$

3) Title:
a) Practitioner
b) $\mathrm{PhD}$
c) Assis. Prof.Dr
d) Assoc.Prof.Dr.
e) Full Professor

4) Area of speciality:
a) Reproduction
c) Internal Medicine
b) Surgery
d) Other (please indicate)

5) How would do you define your establishment?
a) Clinic
b) Polyclinic
c) Hospital
d) University hospital
6) What is the area of your practice?
a) Small animal
b) Equine
c) Farm animals
d) Mixed practice

7) Place of clinic or hospital:
City
/ Province

8) Number of veterinarians working in your practice.
a) 1
b) 2
c) 3
d) 4
e) $\geq 5$

9) How many hours do you give service per day?
a) 8 hours
b) 12 hours
c) 24 hours
d) Other (please indicate) ___ hours

10) School of graduation?

a) University

11) Year of graduation?
a) $1980-1985$
b) $1986-1990$
c) $1991-1995$
d) $1996-2000$
e) $2001-2006$

12) For how long you have been practicing veterinary medicine?
a) 1-4 years
b) 5-9 years
c) $10-19$ years
d) 20-30 years

13) What is the ratio of your patients in your clinic/hospital?

a) More feline patients

b) More canine patients

c) Approximately the same

14) Which contraception method do you recommend or use in dogs and cats?
a) Spaying
b) Hormones
c) Physical restraining
d) Intrauterine device 
e) Other (please indicate)

15) If your answer to question $\mathrm{N}^{\circ} 14$ is "hormones", please indicate the drug:

a) Megestrol acetate e) Other (please indicate)

b) Medroxyprogesterone acetate

c) Proligestone

d) Gonadotrophin releasing hormone (GnRH) implants

16) At what age do you recommend or use hormonal contraception in dogs and cats?
a) Prepubertally
b) After first estrus
c) Anytime
d) Other (please indicate)

17) Do you prescribe human drugs for contraception in companion animals?
a) Yes
b) No

18) If your answer is to question $\mathrm{N}^{\circ} 17$ is "yes", please indicate ...

19)

\begin{tabular}{|l|l|}
\hline \multicolumn{1}{|c|}{ Name of the drug } & Frequency \\
\hline a) & \\
\hline b) & \\
\hline
\end{tabular}

Do you perform spaying for contraception in your clinic/hospital?
a) Yes
b) No

20) Who performs spaying in your clinic/hospital?

a) You or a practitioner full time working in your clinic/hospital

b) Always a practitioner part time working in your clinic/hospital

c) Always an expert full time working in your clinic/hospital

d) Always an expert invited to perform the sugery, not working in your practice

e) Sometimes a practitioner full time working in your clinic/hospital or sometimes an expert not working in your clinic/hospital

21) Have you seen or assisted a spaying surgery during your veterinary education?
a) Yes
b) No

22) How did you learn to perform spaying?
a) University education
b) Internship during veterinary education
c) $\mathrm{PhD}$
d) From another practitioner
e) After establishing my clinic, I learned by practicing
f) Books
g) Internet
h) Other (please indicate)

23) At what age do you perform spaying in the bitch?
a) $<4$ months
b) 4-6 months
c) $7-12$ months
d) $>12$ months
e) After 1st whelping
f) Depends on the breed
g) I do not recommend
h) Other (please indicate)

24) At what age do you perform spaying in the queen?
a) $<4$ months
b) 4-6 months
c) $7-12$ months
d) $>12$ months
e) After 1st whelping
f) I do not recommend
g) Other (please indicate)

25) Why do you perform at this age group?
a) Safer anesthesia
b) Easier surgery
c) Less peri- and postoperative complications
d) Other (please indicate)

26) What is the approximate cost of spaying in your clinic/hospital (just surgery)?
a) 25-50 Euro
b) 50-100 Euro
c) $100-250$ Euro
d) 250-500 Euro 
e) $500-1.000$ Euro

27) Do you routinely use analgesics before or after spaying?
a) Yes
b) $\mathrm{No}$

28) If your answer to question $\mathrm{N}^{\circ} 27$ is "yes", please indicate the drug.
a) Flunixine meglumine
f) Metamizole sodium

b) Carprofen

g) Other (please indicate)

c) Ketoprofen

d) Aspirin

e) Phenylbutazone

29) If your answer to question $\mathrm{N}^{\circ} 27$ is "yes", please indicate for how long do you use analgesics?
a) First 24 hours
b) 3 days
c) 5 days
d) 1 week
e) Other (please indicate)

30) What premedication do you use for spaying?
a) I do not use
b) Atropine sulphate
c) Glycopyrrolate
d) Other (please indicate)

31) Which preanesthetic drug or drugs do you use for spaying?
a) I do not use
b) Diazepam
c) Propofol
d) Medetomidine
e) Acepromazine
f) Xylazine
g) Etomidate
h) Fentanyl
i) Midazolam
j) Pentobarbital
k) Detomidine

1) Other (please indicate)

32) What type of anesthesia do you perform for spaying?
a) Injectable anesthetics
b) Inhalant anesthetics
c) I decide according to the condition of the patient

33) If your answer to question 32 is "injectable anesthetics", please indicate the drug.

a) Tiletamine-Zolazepam (Zoletil)

b) Ketamine

c) Other (please indicate)

34) If your answer to question $\mathrm{N}^{\circ} 32$ is "inhalant anesthetics", please indicate the drug.
a) Halothane
b) Methoxyflurane
c) Isoflurane
d) Sevoflurane
e) Desflurane
f) Other (please indicate)

35) Please rate the difficulty level of the procedures in spaying $(1=$ very easy; $2=$ easy; $3=$ middle grade difficulty; $4=$ difficult; $15=$ very difficult)
a) Anesthesia
b) Finding of the ovaries and uterus
c) Removal of the ovaries
d) Removal of the uterus
e) Control of hemorrhage

1
1
1
1
1

36) Do you keep the animals in your clinic/hospital after the surgery?

a) Yes

b) No

37) If your answer to question $\mathrm{N}^{\mathrm{o}} 36$ is "yes", please indicate the time.
a) 24 hours
b) 1-3 days
c) 5 days
d) 7 days
e) Other (please indicate)

38) What type of surgery do you perform for contraception in companion animals?

a) Ovariectomy

b) Ovariohysterectomy

c) Unilateral ovariohysterectomy (removal of only one ovary and the uterus)

d) Hysterectomy 
e) Other (please indicate)

39) Please indicate your site of incision for spaying in the queen.

a) Ventral midline incision

b) Lateral flank incision

c) Other (please indicate)

40) Please indicate your site of incision for spaying in the bitch

a) Midline

b) Lateral flank incision

c) Other (please indicate)

41) Which suture material do you use for the ligation of the reproductive organs?
a) Plain catgut
b) Chromic catgut
c) Polyglycolic asid (Polyglactin 910)
d) Silk
e) Monofilament non-absorbable suture
f) Other (please indicate)

42) Do you recommend mating or whelping before spaying in companion animals?

a) Yes

b) No

43) If your answer to question $\mathrm{N}^{\circ} 42$ is "yes", please indicate your reason.

Thank you very much for your co-operation. 